\title{
Incorporating Controversial Issues in Critical Thinking Lesson: A Case Study of EFL Classroom
}

\author{
Mannujan Mohini Sudha \\ ${ }^{1}$ Department of English, College of Science and Arts for Girls, King Khalid University, KSA \\ Correspondence: Mannujan Mohini Sudha, Department of English, College of Science and Arts for Girls, King \\ Khalid University, KSA. Tel: 966-550-030-287. E-mail: mannujansudha@gmail.com
}

Received: July 1, 2018 Accepted: August 8, 2018 Online Published: August 10, 2018

doi: 10.5539/elt.v11n9p48 URL: http://doi.org/10.5539/elt.v11n9p48

\begin{abstract}
This case study investigated the issue of incorporating controversial topics in EFL classroom of pre-university students and their attitude toward such controversial topics namely, E-stalking in terms of their own cultural background. The objective of the study was to bring a new dimension in language teaching and learning in Bangladeshi educational system by introducing controversial issues in critical thinking lesson plan. Bangladeshi educational system is solely dependent on the grammar-translation method where including the controversial issue in a language classroom is a completely new experiment for both the teacher and learners. BRAC Institute of Language (BIL) of BRAC University is trying to come out from this traditional teacher oriented methods by implementing new modern approaches and techniques for language learning. This case study was a part of teaching critical thinking, aiming to improve their English language learning. The rationale that the study adopts for introducing controversial topics in EFL curricula is based on the assumption that it helps learners in developing their linguistic and cognitive skills, social awareness, emotional well-being and critical thinking that are compatible with the new approaches and methods of teaching EFL. The present study analyzed data that was collected from the students of pre-university (pre-intermediate level) program and found that majority of the students welcomed the topic E-stalking and showed their positive attitude throughout the lesson. This paper also revealed the importance and possible challenges of incorporating controversial topics in EFL classroom. This study ended with some recommendations made by the researcher's own observation while conducting the lesson.
\end{abstract}

Keywords: a case study, controversial issue, critical thinking, EFL classroom, E-stalking, pre-university, responsible citizens

\section{Introduction}

Controversial issues are not to be avoided but to be embraced if discussed properly (Burron, 2006). Bangladeshi educational system is based on traditional education system where including the controversial issue in a language classroom is a matter of challenge. The practice to include the controversial issue in a classroom is getting importance globally as it improves learners' critical thinking.

Controversy, conflict, and disagreement in classroom are integral elements of teaching, and all instructors must anticipate controversy and plan to use it productively ("Teaching Controversial Issues", 2004).

The Bangladeshi learners are culturally passive learners whereas most of the classrooms are solely teacher-centred. They completely rely on the teachers to clarify and solve their problems raised and discussed in the classroom because they lack autonomy in a language classroom. We get to know about Bangladeshi learners from Shaila and Trudell (2010) that oftentimes, they have only experienced teacher-centred instruction, where they were passive learners or mere memorizers of rules. Critical thinking was not a part of the curriculum, and they did not have the opportunity to develop metacognitive strategies to help them organize, plan, and make decisions about their learning (Shaila \& Trudell, 2010). In response to the crisis, BRAC Institute of Languages (BIL) of BRAC University, which started its journey as CfL (Center for languages) in 2005 with a vision to develop its students' English proficiency, has realized the significance of facilitating critical thinking in language classrooms. With the initiative and assistance of one of its foreign faculty members, Beth Trudell, BRAC Institute of Languages (BIL) first introduced the Critical Thinking approach to teaching English to Pre-University students (pre-intermediate level) in Spring 2008. Acknowledging the success, BRAC Institute of Languages (BIL) has introduced critical thinking approach to the other advanced proficiency level (intermediate 
and advanced) courses (S. Banerjee \& S. N. Banerjee, 2009). BRAC University organized a wide range of workshops and trainings for the faculty members related to teaching Critical Thinking approach. The aim was to make the teachers able to deal with critical thinking lessons successfully. The workshops were on lesson plan, teachers' role, and classroom techniques of Critical Thinking approach. It is worth mentioning that to teach critical thinking the teacher should have enough knowledge and training in the techniques of using critical thinking. Peer observation was also a part of the teaching in BIL. In this way, the new faculty members could improve their teaching techniques by observing experienced teachers' lessons and receiving constructive feedback from their peers for their own lesson. The researcher taught critical thinking as a part of language learning to the pre-university learners for one year. These workshops, trainings, and peer observation made the researcher more knowledgeable and confident to conduct critical thinking lessons. While teaching critical thinking at pre-intermediate level, for a particular lesson, the researcher chose to add a controversial issue in the language-learning lesson. The present study investigated the attitude of the learners toward the particular lesson. The aim of the study was to find out:

1) How successful the lesson was

2) Whether it was accepted or not by the students

3) Whether the students were involved in the discussion or avoided the discussion

4) The challenges the researcher faced

It was an experimental lesson and completely new to the learners. Bangladeshi learners are not accustomed to discussing any controversial or taboo issue in the classroom. Therefore, it was a challenge for the researcher. She included a controversial issue in the language teaching lesson, keeping in mind that it would help the learners to improve their analytical ability, make them socially responsible and involve them more in a discussion.

The researcher used believing and doubting technique of Critical Thinking approach for this lesson as it is considered a very effective activity for critical thinking lesson. According to Shaila and Trudell (2010), an important technique to get students to look at both sides of an issue is based on Elbow's (1986) believing and doubting game. In this activity, students work in pairs and take turns supporting and arguing against the same issue. As they determine what is wrong with an argument they must also focus on the merits of the opposite position. This activity encourages students to put themselves in another's shoes and to have empathy with another's opinion. At the end of the activity, each student attempts to guess his or her partner's true belief, and students try their best to fool their partners.

\section{Literature Review}

\subsection{What Is a Controversial Issue?}

There is no agreed definition of what makes a controversial issue but for the purpose of this paper controversial issues can be defined as those which:

- Evoke strong feelings and views.

- Affect the social, cultural, economic and environmental context in which people live.

- Deal with questions of value and belief, and can divide opinion between individuals, communities and the wider society.

- Are usually complicated, with no clear "answers" because they are issues about which people often hold strong views based on their own experiences, interests, values and personal context.

- Arise at a range of scales, affecting local, national and global communities.

- Include a wide range of topics such as human rights, gender, justice, migration and climate change.

- Can vary by place and time, and may be long standing or very recent. For example, an issue that is controversial in one community or country may be widely accepted in another (Global Citizenship Guides, Oxfam 2006)

Global Citizenship Guides, Oxfam (2006, p. 2), further states, "Almost any topic can become controversial if individual groups offer differing explanations about events, what should happen next and how issues should be resolved, or if one side of an issue is presented in a way that raises the emotional response of those who might disagree." Harwood and Hahn (1990) consider discussion of controversial issues as reflective dialogue among students, or between students and teachers, and about an issue on which there is disagreement.

The scope of issues that might be considered controversial is quite broad. The content of issues may vary from 
local problems to issues on the international scene. The censoring of books in a school library, the immigration policy of the United States, and the environmental state of the world would each prove to be rich subjects for controversial issue discussions. Although each reflects a problem area at a different level of public policy making, they are all topics that foster a wide range of sharply differing opinions (Harwood \& Hahn, 1990).

\subsection{The Importance of the Controversial Issue in Critical Thinking Lesson}

The recent movement of "Critical Thinking" in classrooms has expanded the view of the teaching-learning situation largely, transforming students from passive to active learners. The movement defines thinking as "a process which stresses an attitude of suspended judgment, incorporates logical inquiry and problem solving, and leads to an evaluative decision or action" (Carrol, 1989 as cited in S. Banerjee \& S. N. Banerjee, 2009).

Huitt (1998) stipulates that in the information age, thinking plays a significant role in one's success in life. He goes on to say that, the movement toward the information age has shifted attention to good thinking as a significant element of life success (Rezaei, Derakhshan, \& Bagherkazemi, 2011, p. 769).

In a similar vein, Chaffee (1985) and Paul (1995) mention that enhancing students' critical thinking abilities is the core of meaningful education. Chaffee (1985) explains that meaningful education prevents students from getting involved in the unreflective learning of information, and equips them with the tools necessary to understand thoroughly the world they are in (Rezaei et al., 2011, p. 769).

"Why should we be concerned about critical thinking in our classrooms? Obviously, we want to educate citizens whose decisions and choices will be based on careful, critical thinking. Maintaining the right of free choice itself may depend on the ability to think clearly. Yet, we have been bombarded with a series of national reports, which claim "Johnny can't think" (Mullis, 1983; Gardner, 1983)." All of them call for schools to guide students in developing the higher level thinking skills necessary for an informed society (Tama, 1989).

Controversial issues are more suitable for Critical thinking lessons as they spark the discussion, debate and disagreement. "Teaching Controversial Issues" (2004) expresses the same idea that without controversy (or at least, disagreement), teaching students to think critically is extremely difficult, if not impossible. Knowing how to handle controversy and conflict productively is, therefore, an essential skill for all college teachers ("Teaching Controversial Issues", 2004)

While reading other people's opinions, even a range of opinions is usually not sufficient to encourage critical thinking in the majority of students. To do this, students must become immersed in these issues. They need to relate the issues to their own lives. They need to think and talk about the issues in the first person. A good way to do this is through the use of an in-class exercise to promote critical thinking with active learning techniques (Ebert-May et al., 1997, as cited in Berkson, 2003).

About the importance of using controversial issues, Global Citizenship Guide, Oxfam (2006) describes in the controversial guide that developing and strengthening values of empathy and respect will, therefore, enable young people to contribute to social change as global citizens. Teaching controversial issues can make a significant contribution to delivering Spiritual, Moral, Social and Cultural solutions. Developing and strengthening values of empathy and respect will enable young people to contribute to social change as global citizens. Self-esteem, crucial to global citizenship education and supporting personal and academic development, is a pre-requisite for debating wider global issues if young people are to handle disagreement and acknowledge other people's viewpoints. By actively participating in difficult arguments and debates, young people learn to make reasoned judgements, respect the opinions of others, consider different viewpoints and resolve conflicts. These skills enable them to build resilience and confidence to manage conflicts that arise in response to global issues and in their own lives, whether this is in the playground, at home, or in their local community.

Some instructors use controversy deliberately, planning for discussion and debate as integral elements of their courses. Research has shown that this kind of "intentional engagement" is very effective in promoting higher-level thinking in students ("Teaching Controversial Issues," 2004). Preparing students for participation in such discussions involve an investment of time to train students in discussion techniques (Harwood \& Hahn, 1990). Many reasons have been given to support the use of controversial issues discussions in social studies classrooms. Three of the most prevalent are (1) preparing students for their roles as citizens in a pluralistic democracy, (2) developing critical thinking skills, and (3) improving interpersonal skills (Harwood \& Hahn, 1990).

Global Citizenship guide, Oxfam (2006, p. 5) says, "Using material that is challenging and which leads young people into discussing emotive issues can encourage them to develop the following thinking skills:

- Information processing: gathering, sorting, classifying, sequencing, comparing and contrasting information; 
and making links between different pieces of information.

- Reasoning: justifying opinions and actions; drawing inferences and making deductions; using appropriate language to explain their views; and using evidence to back up their decisions.

- Enquiry: asking relevant questions; planning what to do and how to research; predicting outcomes and anticipating responses; exploring theories and problems; testing conclusions; and refining ideas and opinions.

- Creative thinking: generating and extending ideas; suggesting possible hypotheses; using their imagination; and looking for alternative outcomes.

- Evaluation: evaluating what they read, hear and do, to judge the value of their own and others' work or ideas; being able to not take all information at face value; and to have confidence in their own judgements. "

In relation to making the learners socially responsible, Cook (1984) suggests that when approached correctly, teaching controversial issues in the classroom can help develop students into citizens who will be more likely to deal intelligently and decisively with complex issues (Cook, 1984).

It is very important to follow an appropriate approach to teach controversial issues. Johnson, Johnson, and Holubec, (1992) supported "Structured controversy" approach which is a somewhat more challenging approach, moves the focus of control from the teacher to the students. The goal of this approach is to resolve conflicts between different viewpoints, and it is a well-established strategy in courses based on a cooperative learning model (Johnson et al., 1992; Johnson et al., 2000). This technique can be adapted for use in larger groups and many variations are possible. For example, some teachers may prefer to use only the first part of the process and not require that students argue both sides of an issue (Payne \& Gainey, 2000). In another variation, the teacher requires individual students to research both sides of a controversy on their own and write papers supporting each side. In class, the students are divided into "pro" and "con" groups that debate the issues and develop their best arguments. The teacher then asks them to develop a compromise statement acceptable to both sides. In any case, the instructor should always provide detailed instructions and "rules of engagement" that promote the use of fact-based arguments and help students discuss emotionally-charged issues courteously and rationally (Watters, 1996).

\subsection{A Teacher's Role to Teach the Controversial Issue}

In addition, teachers are solely responsible to create a positive environment for teaching controversial issues. "Teaching Controversial Issues," (2004) reminds us of the responsibility of the instructor by saying "Instructors who are accustomed to using controversy as a teaching strategy understand that they must prepare the students mentally and emotionally for the experience." The positive environment is extremely needed to make students comfortable. Hahn, Angell and Tocci (1988) claim that when students are allowed to discuss controversial issues in an open supportive classroom environment there are often positive outcomes for students' feelings of political interest, efficacy, confidence, and trust (Hahn, Angell, \& Tocci, 1988, cited in Harwood \& Hahn, 1990).

\section{Harwood and Hahn (1990) point out some KEY CONSIDERATIONS FOR IMPLEMENTING} CONTROVERSIAL ISSUES DISCUSSIONS IN THE CLASSROOM

Conducting beneficial discussions of controversial issues is an art that requires skill and practice. Teachers must pay careful attention to preparation for discussions, and the role they will take during the conduct of the discussion to ensure that interactions will be fruitful. Each of the following points should be considered.

- Selecting Issues

- Preparing Students for Discussion

- Providing Adequate Information Sources

- Establishing an Open Discussion Climate

- Maintaining Focus and Direction

- Ensuring Intellectual Balance

- Encouraging Equal Participation

- The Expression of Teachers' Personal Views (Harwood \& Hahn, 1990)

Perry (1970) clearly states that students may not be "developmentally ready" for critical thinking when they enter our classrooms. In order to address controversial issues, teachers must first understand that these students may react very negatively to the whole idea. Global citizenship guides, Oxfam (2006) indicates that the concept of balancing rights is important to consider. One young person may express views that diminish another's right 
to feel safe and secure in the classroom. Setting the boundaries for an inclusive discussion where all young people are able to participate is important. This can be achieved by establishing ground rules. Global citizenship guides, Oxfam (2006) added that before launching into your chosen activity, it is important to establish ground rules which are designed to provide a safe environment for pupils to express their opinions. It is important for you to judge when, how and if to express your own views and opinions.

In order to effectively address controversial issues in the classroom, all teachers should be able to teach students an analytical process called Issues Analysis. Issues Analysis is a critical thinking/critical reading procedure that can be applied to any controversial issue in any subject area. The goal of Issues Analysis is to prepare students to assume the role of exercising responsible citizenship in a free society. It shows students how to objectively evaluate various perspectives on major issues. It teaches them how to anticipate barriers to achieving acceptance of their point of view. They are enabled to assert their positions in ways that have the highest probability of efficacy (Burron, 2006).

\section{Methodology}

\subsection{Participants/Subjects}

The participants were 67 students (44 male students and 23 female students) from 3 sections who attended a General English course for the pre-intermediate level in BRAC Institute of Language, BRAC University. The age group of the participants was from 19-23. The researcher chose these particular students as she was teaching them at the pre-university level and included controversial issue as part of critical thinking lesson.

\subsection{Data Collection Procedure}

\subsubsection{Questionnaires}

Critical thinking approach was incorporated in this foundation course, aiming to boost their language learning. Controversial topic namely, E- stalking was introduced in one lecture and the lecture consisted of two sessions where each session was 80 minutes long.

After completing the lecture, students were given some questionnaires to get the immediate reflection of their attitudes and responses regarding this new experiment.

The major focus of the research was to get the immediate feedback of the target learners about the particular lecture and to find out the effectiveness and the challenges of incorporating controversial issue in the language classroom.

The questionnaires for the students were both qualitative and quantitative. The quantitative questionnaire consisted of 6 questions and the qualitative questionnaire consisted of 3 questions.

To find out students' actual attitude to the lesson, the qualitative questions were targeted to find out mainly (i) students' response after the lesson, (ii) if they found any different reaction from the other peers about the lesson (iii) what positive changes they noticed in English language skills for that particular lesson.

\subsubsection{Class Observation of the Researcher}

As an experimental lesson, the researcher added a controversial issue in language classroom in critical thinking lesson and she monitored and observed the whole lesson carefully. So participants observation by the researcher is also considered as the medium to understand the efficacy of this lesson. She monitored every single response of the students during the lesson aiming to find out the attitude of the learners, their interest or disinterest toward the activity of the lesson, their participation on that day and the challenges the students faced in that lesson. The following lesson plan was prepared and followed by the researcher for the target lesson.

$1^{\text {st }}$ session

Step-1: 20 minutes

At the very beginning of the lesson, the teacher introduced the topic E-stalking to the students. She tried to bring out the ideas of E- stalking through showing some pictures/videos.

The students were provided with a reading text on E-stalking one day before the target lesson and were asked to go through it as a homework, so it was presumed that students got some light on the topic and were mentally prepared for the lesson.

For introducing the idea, the following questions were asked to involve the students in a lively discussion and to prepare them mentally and emotionally for the next session. It was a sort of very casual discussion to create a friendly environment for the target learners. 
1) What is E-stalking?

2) Have you ever become a victim of E-stalking? Relate your story.

3) Why do people do E-stalking?

Step-2: 15 minutes

Next, the focus was on the reading text, which was given one day prior to this lesson as their homework. Students were occupied in-group discussion and talked about the main points of the selected text on E-stalking. Some students who did not read the text before, got the ideas and summary of the text by discussing with each other.

Step-3: 10 minutes

After that, the teacher provided the worksheet to the students and asked them to match some words with their appropriate meanings. In this activity, they learned some new vocabularies. After the matching, they did peer checking.

Step-4: 35 minutes

Students were divided into four groups. Each group brainstormed and shared the ideas among themselves in related to the following two questions. The teacher asked them to write three main points for each question on the poster and then to present it.

1). What are the consequences of E-stalking?

2). Can you think of ways to prevent or minimize E- stalking?

$2^{\text {nd }}$ session

Step 1: 80 minutes

The teacher put the students into two groups. After that, the teacher wrote down the following topics on the board and asked the students to make notes for their argument as both a believer and a doubter. The teacher gave the instruction to the students to provide enough reasons and examples about the topics, both from the positive and negative sides. Then the instructor selected four presenters randomly from each group to make their presentation. When one group was doing their presentation on poster papers, the other group was giving feedback on the group presentation assessment form. The same process followed by the other group as well.

Topics:

1) The adults are responsible for E-stalking. They could have stopped it.

2) E-stalkers should get the death penalty.

3) The girls who committed suicide are the only persons accountable.

4) We should stop using mobile phone and internet to stop E- stalking.

Step-2

The teacher asked the students to write a letter as their homework.

Write a letter to your friend telling her/him that E- stalking is not an innocent fun. It is illegal.

\section{Result and Discussion}

\subsection{Findings from Students' Responses}

\subsubsection{Quantitative Questionnaires}

The students were requested to indicate on a four-point scale to show whether they strongly agreed, agreed, disagreed, or strongly disagreed about each of the statements provided in the questionnaire.

Findings from the quantitative questionnaire showed that $97 \%$ respondents strongly agreed with the first statement that they welcomed E-stalking as an appropriate topic for discussion in the language classroom. 3\% of students agreed with the statement and no one showed their negative attitude toward the topic which indicates that all of them accepted E- stalking as an appropriate topic for discussing in the language classroom. $60 \%$ of students strongly agreed and $13 \%$ of students agreed with the second statement that the topic is common in their own cultural context. $27 \%$ respondents did not think E-stalking matched with their cultural context. No one strongly disagreed with the statement. In relation to the response of the following statement, $85 \%$ students strongly agreed that they became more aware of this issue after the lesson and this particular lesson drew their attention to their responsibility to their society. $13 \%$ students agreed with this statement where $2 \%$ of students 
did not get any influence to be socially responsible from this lesson and showed their opinion by marking the statement as disagree. There was no response for strongly disagreed column. In response to the $4^{\text {th }}$ statement, $60 \%$ respondents strongly agreed and $27 \%$ students agreed and mentioned that the topic is important to discuss in the class and they were happy with the lesson and considered it as effective. 13\% students disagreed and stated that the lesson was not good enough and they did not find the importance of the topic to be discussed in this lesson. No one strongly disagreed with the statement. For the fifth statement, $72 \%$ of students strongly agreed and 15\% agreed and showed their interest to have more lessons on controversial issues whereas $13 \%$ disagreed and disliked the controversial topics for classroom discussion.

The last component of the questionnaire indicated that $86 \%$ learners were quite happy with the environment of the classroom and they strongly agreed with it. $12 \%$ of students agreed with them and showed their satisfaction with the teacher, how she introduced the topic and created the positive environment for the lesson. $2 \%$ of students were not happy with the environment of the respective classroom and disagreed with the statement. No one strongly disagreed with this component.

Table 1. The average response from the respondents

\begin{tabular}{|c|c|c|c|c|}
\hline Statements & $\begin{array}{l}\text { Strongly } \\
\text { Agree }\end{array}$ & Agree & Disagree & $\begin{array}{l}\text { Strongly } \\
\text { Disagree }\end{array}$ \\
\hline $\begin{array}{l}\text { 1. The topic like E-stalking is appropriate to discuss in the } \\
\text { classroom }\end{array}$ & $97 \%$ & $3 \%$ & $0 \%$ & $0 \%$ \\
\hline 2. The topic matched with your own cultural context & $60 \%$ & $13 \%$ & $27 \%$ & $0 \%$ \\
\hline 3. The lesson influenced you to be socially responsible & $85 \%$ & $13 \%$ & $2 \%$ & $0 \%$ \\
\hline $\begin{array}{l}\text { 4. The lesson was effective enough to convince you about its } \\
\text { importance }\end{array}$ & $60 \%$ & $27 \%$ & $13 \%$ & $0 \%$ \\
\hline $\begin{array}{l}\text { 5. Such kind of topics like E-Stalking should be discussed more } \\
\text { in class }\end{array}$ & $72 \%$ & $15 \%$ & $13 \%$ & $0 \%$ \\
\hline $\begin{array}{l}\text { 6. The teacher was able to ensure a healthy class environment } \\
\text { while introducing the topic }\end{array}$ & $86 \%$ & $12 \%$ & $2 \%$ & $0 \%$ \\
\hline
\end{tabular}

\subsubsection{Qualitative Questionnaire}

(i) What is your response/feelings about the lesson?

Almost all students welcomed this issue in the language classroom. Students responded to this question that this lesson made them think over this issue E-stalking. Before this lecture, they never thought about the issue seriously and they did not have any idea about the consequences and the reasons behind it. After the lesson, they came to know about the bad effects and the distressing result of it and even the ways to stop E-stalking. One student mentioned, "This topic helped us to open our eyes." This discussion made them aware of this issue and they got the ideas about how they could stop E- Stalking. Few of them felt an urge to work and create awareness for stopping E- stalking. They enjoyed sharing the stories in the class, which helped them to understand the real results of E- stalking. They showed interest to involve more social issues like E- stalking in future learning lessons and they proposed some social issues like domestic violence, sexual harassment, bullying and so on for further lessons.

ii) What was the reaction of your other classmates to the topic?

Some students' responses revealed that the attitude of the girls was different from the reaction of the boys. They found the girls were feeling shy at the beginning of the lecture but they became more vocal and serious later on. In addition, one respondent gave his own opinion that in Bangladeshi context, mostly girls are the victims of Estalking so the girls participated more to share their feelings as victims and hatred for the E- stalkers. On the other hand, few students did not notice any different reaction from their other classmates. One student mentioned that everyone was keen to know about the topic and enjoyed the lesson because it was new to them.

iii) What positive changes they noticed in their English language skills for that particular lesson

Most of the students expressed that they were more involved in that particular lesson than the other lectures. According to them, as the learners could get an opportunity to express their opinion through presentation and 
discussion, they were passionate to share their emotions and ideas. They participated more in general in the whole lesson and in particular, they spoke more in the lesson. Some of them also considered this topic suitable for critical thinking lesson as it improved their thinking ability. They mentioned that they never thought about the issue in depth before but this lesson compelled them to think from a different perspective. One of the respondents opined that during the whole lesson they sometimes responded as victim, sometimes as E-stalker and discussed the reasons, negative outcomes and remedies, which certainly helped them to develop their critical thinking, analytical ability and language skills, especially speaking and reading skills.

\subsection{Findings from Class Observation}

The target of the lesson was to involve students more impulsively in this lesson by using a controversial issue. The teacher was keen to observe every single reaction of the learners about the topic. Introducing the term was in a controlled way, particularly when the students were not acquainted with the topic which was found to be effective for a controversial issue related lecture. While introducing the term, students got time to be mentally prepared for the impending lesson. Through this introductory time, the teacher got a chance to monitor the reaction of the learners to the topic and could assume whether the topic would work or not.

At the very beginning of the lesson, the researcher found that the students felt shy and embarrassed. They did not want to open up in front of the class. Sometimes they seemed to be very confused about why they were discussing this type of topic in the class.

The researcher found that this topic helped the students to be aware of the negative outcomes of E- stalking. Through the lesson, the students felt the harmful result of E- stalking. When one female student was sharing her sufferings and becoming emotional, the other students regretted doing E stalking sometimes and confessed that before this lesson they did not think of the devastating result of E- stalking and the feelings of the victim. One student also shared that he was E- stalking before but when he saw his own sister was victimized by E-stalking, he stopped to E-stalk.

As learning was the most important factor for the students, so how much students were involved in the classroom discussion was monitored. The researcher found that the learners were rigid for half of the first session but after that when students felt free to get involved in the discussion, they were very spontaneous and enjoyed the session and more participation was considerably generated for the following session. In particular, some introvert students also tried to take part in the discussion and expressed their opinions.

\subsection{Challenges}

The researcher faced the following challenges to conduct the lesson.

- To introduce the topic

- To ensure a healthy classroom environment

- To make students get involved in the class

4.3.1 Recommendation

After conducting the lesson, the researcher makes the following suggestions for conducting a successful lesson and overcoming the challenges, in conducting controversial related lessons.

- Selecting issues is very important to introduce controversial issue in a language classroom. According to Harwood and Hahn (1990), in selecting discussion issues, teachers should consider their students' interest, experience, and expertise regarding the issue; the relevance of issues to their students' lives; their students' maturity level; and the significance of the issue to society.

Accepting the opinion, the researcher selected the topic E- stalking considering the socio-cultural background of Bangladeshi learners. In Bangladeshi context E-stalking or cyberstalking is a very common issue where the victim and the responsible in most of the cases are young people. The topic is well known to the learners, which they can relate with their own life, to think critically. The researcher chose the topic in this way that the students should have knowledge about the topic and they could relate the topic to their own life because if the topic is not related to their life or if they do not encounter the situation in their real life, they could not be engaged more in the discussion. The researcher considered the topic E- stalking, keeping in mind that students are more or less victims of E- stalking and some students were responsible for E- stalking people. It made a great debate that only males are responsible or girls also E- stalks; in proving their points, they were sharing their experiences of being E- stalked by the opposite gender. 
- If the teacher plans to provide the reading material to the students, she/he should be aware not to choose any biased reading. If the teacher plans to include controversial issue aiming to involve students more in discussion or debate, the reading material will help them to accumulate the ideas. Thus, it is important to select a reading text, which will help them to get all the information about the topic.

- The teacher has a great responsibility in handling controversial issue related lesson. It is very important to provide a friendly and comfortable environment for the learners. When the teacher is introducing any controversial issue in the language classroom, she should explain or clarify the importance of the issue, which is to be discussed in the classroom. The learners should not have any confusion or negative attitude toward the topic. It is completely the teacher's responsibility to make students comfortable and be prepared for the lesson.

- Implementing controversial issue in a language classroom can be more beneficial if it is included in the middle of the semester because the teacher and the students will get enough time to build up a rapport with each other. At the beginning of the semester, students may feel more uncomfortable in front of the teacher. If it is conducted by the middle of the semester, by this time the teacher would have known about his/her students better, which will help him/her to select the topic and plan the lesson.

- "Successfully negotiating discussions of controversial issues (whether planned or spontaneous) also depends strongly on the instructor's knowledge of the students - their backgrounds, attitudes, beliefs, and expectations. Previous experience in teaching a course provides some clues about the topics and issues that may elicit disagreement or dissent, but an intimate knowledge of the students in each class enables the instructor to tailor his/her facilitation to achieve the maximum benefit" ("Teaching Controversial Issues", 2004 ). The teacher may take more time to create a friendly environment in the classroom to help students participate more. It is also important to ensure that every student gets along well with other students. The article of the magazine in The University of Queensland also mentioned that 'Getting to know each other enhances students' ability to communicate and enhances participation'("Inclusive Practices for Managing Controversial Issues" n.d.). The more students will be "fear free" and comfortable in the lesson the more they will be spontaneous in their responses. If the lesson is conducted in the middle of the semester, the teacher would have had enough time to monitor their usual responses in the class and then she can compare their responses during that particular lesson where she uses the controversial issue to determine the success or limitations of the lesson.

- Relating one's own story is a very effective technique to create a positive environment and to make the learners comfortable. (Harwood \& Hahn, 1990) suggest that one can express personal perspectives when appropriate without promoting that position to the students (Harwood \& Hahn, 1990). In this particular lesson, the students seemed confused and shy at first. In the first 20 minutes, when the teacher was trying to introduce the topic by asking them questions related to their experience, they were feeling uncomfortable and uninterested to share their stories. Therefore, the teacher shared her own experience related to E- stalking keeping the intention to integrate the students and finally the conversation went on successfully. The teacher allowed and welcomed the students to bring their own experiences and perspectives to the problems investigated in the class. By that time, students got involved slowly in the discussion and became excited to share their experiences. Surprisingly the researcher noticed that students were so spontaneous that they all engaged in sharing their stories and getting involved in the lesson.

- If the teacher wants to get the feedback of her/ his lesson from the students to determine whether the topic works or not, he/she should take the responses from the students immediately after the lesson. These responses will help the teacher to understand the authentic reaction of the students and will help him/her to select the topics and make the lesson plans for future lessons.

\section{Conclusion}

Implementing E- stalking as a topic for classroom discussion was a very new experience for the researcher and for the learners as well. In Bangladeshi perspective, students do not encounter any controversial issue in classroom discussion. During primary and secondary education, they encounter the traditional grammar-translation method. According to Jabeen and Hyder (2012), Teaching and learning English at the primary and secondary levels in Bangladesh are generally grammar based as it is an 'easy' method to follow. In addition, Jabeen and Hyder (2012) mention that the language learning is confined to the classroom learning and the examination scripts. Students get 'input' through reading and listening but as soon as students come out of the class they do not get an exposure to the English language.

In tertiary level, very few universities aim to improve students' analytical ability besides language learning. BRAC University is one of them, which considered improving the students' analytical and critical thinking in addition to language learning. Shaila and Trudell (2010) also emphasize the importance of teaching critical 
thinking for Bangladeshi learners. "The ability to think critically is especially important for students living in a country with political and socioeconomic problems, for it will help them to look at issues from different viewpoints and become independent thinkers and responsible citizens." (Shaila \& Trudell, 2010).

BRAC Institute of Languages (BIL) of BRAC University welcomes new approaches and teaching techniques from all the faculty members. In response, the researcher got interested and was encouraged to do something new and challenging but effective for the language classroom.

This study revealed that Bangladeshi learners are keen to learn in learners' autonomy environment. They liked the different approach of teaching style than the traditional teaching. They welcomed and enjoyed controversial topic E- stalking in the classroom and they suggested many topics for further lessons.

From the students' responses and her own observation, the researcher found the lesson was successful; in Bangladeshi context, controversial issues can be taught in a controlled way, which really helps the learners to be better critical thinkers, socially responsible and spontaneous in their responses to improve their language learning. Although the researcher found some challenges, the prospects of the approach are significant and effective.

\section{References}

Banerjee, S., \& Banerjee, S. N. (2009). Critical Thinking Approach to Language Teaching: A Case Study. Journal of the Institute of Modern Languages, 22.

Berkson, J. (2003). Advocacy, Critical Thinking, and the Classroom. American Fisheries Society (FISHERIES), 28(9), 23-26.

Burron, A. (2006) Controversial Issues: They Belong in the Classroom. Education Policy Center. Independence Institute.Org. Retrieved from https://www.procon.org/sourcefiles/they_belong_in_the_classroom_4-06.pdf

Carrol, T. M. (1989) Critical Thinking: Promoting It in the Classroom. ERIC Clearinghouse on Reading and Communication Skills. Bloomington IN (available through ERIC, ED306554).

Chaffee, J. (1985). Thinking critically. Boston: Houghton Miftlin Company.

Cook, K. (1984). Controversial Issues: Concerns for Policy Makers. ERIC Digest No. 14. June 1984. ERIC Document Reproduction Service ED253465.

Ebert-May, D., Brewer, C. A., \& Allred, S. (1997). Innovations in Large Lectures: teaching for active learning through inquiry. Bioscience, 47, 601-607. https://doi.org/10.2307/1313166

Gardner, D. P. (1983). A Nation at Risk: The Imperative for Educational Reform. An Open Letter to the American People. A Report to the Nation and the Secretary of Education. Washington, DC: National Commission on Excellence in Education.

Harwood, A. M., \& Hahn, C. L. (1990). Controversial Issues in the Classroom. ERIC Clearinghouse for Social Studies/Social Science Education Bloomington. Retrieved from https://www.ericdigests.org/pre-9218/issues.htm

Hahn, C. L., Ann, A., \& Cindy, T. (1988). Civic Attitudes in Five Nations. A paper presented at the International meeting of the Social Studies, Vancouver, British Columbia, Canada.

Huitt, W. (1998). Critical thinking: An overview. Educational Psychology Interactive.

Jabeen, F., \& Hyder, E. (2012). Centre for Languages: An innovative pace in language Learning and Teaching-making a difference in the context of Bangladesh. Annual International Conference on Language, Literature and Linguistics. https://doi.org/10.5176/2251-3566_L31272

Johnson, D. W., Johnson, R. T., \& Holubec, E .J. (1992). Advanced cooperative learning. Edina, MN: Interaction Book Co.

Johnson, D. W., Johnson, R. T., \& Smith, K. J. (2000). Constructive controversy: The educative power of intellectual conflict.

Mullis, V. S., \& Mead, N. (1983). How well can students read and write? Issuegram 9. Denver: Education Commission of the States.

Paul, R. W. (1985). Bloom's taxonomy and critical thinking intervention. Educational Leadership, 42(8), 36-39.

Payne, B. K., \& Gainey, R. R. (Fall, 2000). Understanding and developing controversial issues in college courses. Journal of Criminal Justice Education, 11, 2. https://doi.org/10.1080/10511250000084941 
Perry, W. G. Jr. (1970). Intellectual and ethical development in the college years. New York: Holt, Rinehart \& Winston

Rezaei, S., Derakhshan, A., \& Bagherkazemi, M. (2011). Critical Thinking in Language Education. Journal of Language Teaching and Research, 2, 769-777. https://doi.org/10.4304/jltr.2.4.769-777

Shaila, Y. M., \& Trudell, B. (2010). From Passive Learners to Critical Thinkers: Preparing EFL Students for University Success. English Teaching Forum, 48(3), 2-9.

Shirkhani. S., \& Fahim, M. (2011). Enhancing Critical Thinking in Foreign Language Learners. Elsevier Ltd. Prpcedia Social and Behavioral Sciences, 29, 111-115. https://doi.org/10.1016/j.sbspro.2011.11.214

Tama, M. C. (1989). Critical Thinking: Promoting It in the Classroom. ERIC Clearinghouse for Social Studies/Social Science Education Bloomington IN. Retrieved from http://ericae.net/edo/ed306554.htm

Teaching Controversial Issues. (2004). CTL: Publications: For Your Consideration\# 21. Retrieved from https://www.procon.org/sourcefiles/CTL.pdf

Watters, B. (1996). Teaching peace through structured controversy. Journal on Excellence in College Teaching $71,107-125$.

\section{Copyrights}

Copyright for this article is retained by the author(s), with first publication rights granted to the journal.

This is an open-access article distributed under the terms and conditions of the Creative Commons Attribution license (http://creativecommons.org/licenses/by/4.0/). 